\title{
Tailoring Water Adsorption Capacity of APO-Tric ${ }^{\dagger}$
}

\author{
Suzana Mal ${ }^{1,2}$, Alenka Ristić ${ }^{1, * \mathbb{D}}$, Amalija Golobič ${ }^{3}$ and Nataša Zabukovec Logar ${ }^{1,4}$ \\ 1 National Institute of Chemistry, Hajdrihova 19, SI-1001 Ljubljana, Slovenia; suzana.mal@ki.si (S.M.); \\ natasa.zabukovec@ki.si (N.Z.L.) \\ 2 Jožef Stefan International Postgraduate School, Jamova cesta 39, SI-1000 Ljubljana, Slovenia \\ Faculty of Chemistry and Chemical Technology, University of Ljubljana, Večna pot 113, \\ SI-1000 Ljubljana, Slovenia; amalija.golobic@fkkt.uni-lj.si \\ 4 School of Science, University of Nova Gorica, Vipavska 13, SI-5000 Nova Gorica, Slovenia \\ * Correspondence: alenka.ristic@ki.si; Tel.: +386-1-476-0215 \\ $+\quad$ This paper is an extended version of our paper published in: Mal, S.; Ristić, A.; Golobič, A.; Logar, N.Z. \\ Tailoring Water Adsorption Capacity of Aluminophosphate AlPO-34. In Proceedings of the 15th International \\ Conference on Energy Storage ENERSTOCK2021, Ljubljana, Slovenia, 9-11 June 2021.
}

\section{check for}

updates

Citation: Mal, S.; Ristić, A.; Golobič, A.; Zabukovec Logar, N. Tailoring Water Adsorption Capacity of APO-Tric. Crystals 2021, 11, 773. https://doi.org/10.3390/cryst11070773

Academic Editor: Volodymyr Bon

Received: 27 May 2021

Accepted: 28 June 2021

Published: 2 July 2021

Publisher's Note: MDPI stays neutral with regard to jurisdictional claims in published maps and institutional affiliations.

Copyright: (c) 2021 by the authors. Licensee MDPI, Basel, Switzerland. This article is an open access article distributed under the terms and conditions of the Creative Commons Attribution (CC BY) license (https:// creativecommons.org/licenses/by/ $4.0 /)$.
Abstract: Microporous triclinic $\mathrm{AlPO}_{4}-34$, known as APO-Tric, serves as an excellent water adsorbent in thermal energy storage, especially for low temperature thermochemical energy storage. Increased water adsorption capacity of thermochemical material usually leads to higher thermal energy storage capacity, thus offering improved performance of the adsorbent. The main disadvantage of aluminophosphate-based TCM materials is their high cost due to the use of expensive organic templates acting as structure directing agents. Using ionic liquids as low cost solvents with associated structure directing role can increase the availability of these water adsorbents for TES applications. Here, a green synthesis of APO-Tric crystals at elevated and ambient pressure by using 1-ethyl-3-methyl imidazolium bromide ionic liquid is presented. Large $200 \mu \mathrm{m}$ romboid shaped monocrystals were obtained at $200{ }^{\circ} \mathrm{C}$ after 6 days. The structure of APO-Tric and the presence of 1,3-dimetylimidazolium cation in the micropores were determined by single crystal XRD at room temperature and $150 \mathrm{~K}$. Water sorption capacity of APO-Tric prepared by ionothermal synthesis at elevated pressure increased in comparison to the material obtained at hydrothermal synthesis most probably due to additional structural defects obtained after calcination. The reuse of exhausted ionic liquid was also confirmed, which adds to the reduction of toxicity and cost production of the aluminophosphate synthesis.

Keywords: APO-Tric; water adsorption capacity; thermal energy storage; green ionothermal synthesis; single-crystal structure determination

\section{Introduction}

Microporous aluminophosphates are zeolite-like or zeotype materials which gain a lot of attention in the last years as the advanced water adsorbents for low temperature adsorption heat transformation applications such as thermal energy storage (TES), heat pumps and chillers [1]. These adsorbents known as thermochemical materials (TCMs) rely on reversible physical adsorption and desorption process of gases on porous solids, an essentially exothermic phenomenon. Adsorption-based TES is considered to be quite a promising technology both for seasonal and daily storage applications, nevertheless, its commercial diffusion is still not fully developed, mainly due to its cost and the lack of technical knowledge at a system level, meaning that development and research is still needed in order to make the technology commercially competitive [2]. The current trend is focused on a development of water adsorbents with enhanced adsorption capacity and hydrothermal stability. Increasing water adsorption capacity of TCM material usually leads to higher thermal energy storage density, thus offering improved performance of the adsorbent. The main advantages of the aluminophosphate TES adsorbents are high thermal 
energy storage density, good stability under repeated adsorption-desorption process and, most impostant, significantly lower regeneration temperature, as compared to zeolites, due to hydrophobic-hydrophilic character shown as type V water adsorption isotherm [3]. On the other hand, the main drawback, which limits their use in TES applications, is significant preparation cost, especially when expensive templates or structure directing agents are used such as diethylamine and tetraethylammonium hydroxide [1]. These templates are used, for example, for the synthesis of SAPO-34 [4], which is known as the best proven catalyst for methanol to olefin (MTO) conversion since 1990 [5].

Microporous aluminophoshaptes, discovered in the early 1980s by Union Carbide [6] are crystalline materials, having three dimensional neutrally charged frameworks build of strictly alternating $\left[\mathrm{AlO}_{4}\right]^{-}$tetrahedra, and $\left[\mathrm{PO}_{4}\right]^{+}$tetrahedra, some structures containing also $\left[\mathrm{AlO}_{5}\right]^{-}$and $\left[\mathrm{AlO}_{6}\right]^{-}$polyhedra, with wide range of pore openings, showing great structures diversity. These materials are thermal stable up to $1000^{\circ} \mathrm{C}$ and hydrothermal stable up to $600{ }^{\circ} \mathrm{C}$ in steam.

In the last decade only few aluminophosphate structures were investigated for TES applications, such as SAPO-34 (AQSOA-Z02) with chabazite structure as the most studied [7-11] and commercialized (Mitsubishi Plastics) adsorbent, APO-5 (AQSOA-Z05), FAPO-34 (AQSOA-Z01) [10], APO-18 [1], APO-Tric [9], and APO-LTA [12] (APO-n; $\mathrm{n}=$ structure type). All listed aluminophospahtes have small pore opening (around $0.4 \mathrm{~nm}$ ) with 3D pore arrangements, except FAPO-5 containing 1D pore arrangement with large pore opening of $0.73 \mathrm{~nm}$. Adsorption capacity of aluminophospahtes can be increased by incorporation of silicon or metal (Fe; FAPO) cations into the aluminophosphate framework, introducing structural defects as additional adsorption sites. On the other hand, hydrothermal stability is usually decreased due to dislodgement of the silicon or metal cations from the structure leading to amorphisation of the crystalline structure, for example, SAPO-34 synthesized by using morpholine as the template was not stable under hydrothermal stress [13].

Aluminophosphates are hydrothermally or solvothermally synthesised at relatively high temperatures $\left(120-200{ }^{\circ} \mathrm{C}\right)$ in Teflon-lined stainless steel autoclaves at elevated pressures by using expensive structure-directing agents or organic templates, and chemicals containing $\mathrm{Al}$ and $\mathrm{P}$ atoms. The framework formation can be affected by various parameters, such as the reactants, reaction mixture composition and $\mathrm{pH}$, template chemical structure, solvent type, as well as the crystallization temperature and time. Crystallization at atmospheric pressure can be achieved by ionothermal synthesis, thus eliminating safety concerns, where ionic liquid (IL) has a dual role, i.e., it is used as a solvent and as the template, due to the cation of the ionic liquid, around which the final solid material forms during the reaction process. [14] Ionic liquids are special molten salts that consist of organic cations and inorganic anions with melting temperatures below $100{ }^{\circ} \mathrm{C}$ [15], and are well known as environmentally benign and designable solvents. They have relatively low viscosity, high electric and thermal stability, are good solvents for a wide range of organic and inorganic materials, and, importantly, have negligible vapor pressure [16,17]. These characteristics enable ionic liquids to be widely used as a green solvent. The requirement for ambient pressure is very convenient when it comes to coating substrates and production (»up-scaling «) of materials. Ionothermal synthesis of aluminophoshates was introduced by Morris and his co-workers in 2004 [18], using 1-ethyl-3-methylimidazolium bromide ionic liquid. So far the number of frameworks (AEL, AFO, CHA, SOD, LTA, CLO [19] and new structures) prepared by ionothermal synthesis remains lower than for solvo- and hydrothermal syntheses [20].

Here we present an environmental-friendly template-free synthesis route of APOTric large monocrystals by using 1-ethyl-3-methylimidazolium bromide ionic liquid as a low-cost solvent. Crystal structure of the as-synthesised APO-Tric crystals was determined by single crystal XRD at room temperature and at $150 \mathrm{~K}$, which both revealed the presence of 1,3-dimetylimidazolium cation in the micropores. Textural properties of the calcined APO-Tric prepared at elevated pressure were determined with nitrogen physisorp- 
tion, while hydrophilic character was investigated by gravimetrically measurement of water adsorption.

\section{Materials and Methods}

\subsection{Materials}

Aluminium isopropoxide ( $\geq 98 \%$ ), phosphoric acid ( $>85 \%)$ hydrofluoric acid $(40 \%)$ and ethanol (96\%) were purchased from from Merck (Darmstadt, Germany). 1-ethyl-3methylimidazolium bromide (EMIMBr, 99\%) was purchased from Ionitec (Heilbronn, Germany).

\subsection{Synthesis}

APO-Tric crystals were synthesised from a modified ionogel $[18,19]$ with a reactants molar ratio: $1 \mathrm{Al}_{2} \mathrm{O}_{3}: 1.5 \mathrm{P}_{2} \mathrm{O}: 3.2 \mathrm{HF}: 104$ EMIMBr. The synthesis procedure was as follows: $\mathrm{H}_{3} \mathrm{PO}_{4}, \mathrm{HF}$ and EMIMBr were added together in a beaker. The reaction mixture was stirred and heated to $95{ }^{\circ} \mathrm{C}$ for $1 \mathrm{~h}$. Subsequently, aluminium isopropoxide was added to the reaction mixture which was then stirred for another hour at $95{ }^{\circ} \mathrm{C}$. Half of the mixture was transferred into Teflon-lined stainless steel autoclave and heated in an oven at $200^{\circ} \mathrm{C}$ for 6 days, while the other half was added in the capped glass bottle for crystallization at $200{ }^{\circ} \mathrm{C}$ and ambient pressure for 3 days in the oven. The products were filtered and washed thoroughly with ethanol before drying overnight at room temperature, while filtrate containing ionic liquid was collected and recycled several times. Ethanol was removed by evaporation from the filtrate. Recycled IL was used as the solvent and the structure directing agent for further syntheses of the APO-Tric products. All as-synthesised samples were calcined at $600{ }^{\circ} \mathrm{C}$ overnight in a furnace under air flow to remove the structure directing agent from the micropores.

APO-Tric powder ionothermally prepared at elevated pressure is named APO-Tric-EP, while APO-Tric powdered sample obtained at ambient pressure is denoted APO-Tric-AP. APO-Tric-IL stands for calcined APO-Tric prepared at elevated ionothermal synthesis, while APO-Tric-HT was obtained at hydrothermal synthesis.

\subsection{Methods}

Powder XRD of the sample were collected on a PANalytical X'Pert PRO (Panalytical, Almelo, The Netherlands) diffractometer using $\mathrm{CuK} \alpha_{1}$ radiation $(\lambda=1.5406 \AA)$ at room temperature in the range from 5 to $50^{\circ} 2 \theta$ with step 0.017 per $100 \mathrm{~s}$ using a fully opened $\mathrm{X}^{\prime}$ Celerator detector. Morphology of single crystals was studied by scanning electron microscopy (SEM) on a Zeiss SupraTM 3VP SEM microscope. (ZEISS, Jena, Germany). High Temperature X-ray powder diffraction (HT-XRD, Panalytical, Almelo, The Netherlands) using PANalytical $X^{\prime}$ Pert PRO high-resolution diffractometer in the $2 \theta$ range from $5^{\circ}$ to $50^{\circ}$ using a step of $0.026^{\circ}$ per $100 \mathrm{~s}$. XRPD patterns were collected at constant temperatures between room temperature and $500^{\circ} \mathrm{C}$. Between the scans, the sample was heated at a rate of $10^{\circ} \mathrm{C} / \mathrm{min}$ in air. Single-crystal diffraction data have been collected on an Agilent SuperNova dual source diffractometer with an Atlas detector using a mirror monochromator and MoK $\alpha$ radiation at 150 and $293 \mathrm{~K}$ (Agilent, Santa Clara, CA, USA). The diffraction data were in both cases processed using CRYSALIS PRO software [21]. All structures were solved by direct methods, using SIR97 [22]. Full-matrix least-squares refinements on $F^{2}$ were done with anisotropic displacement parameters for all non-hydrogen atoms. All $\mathrm{H}$ atoms were observed in difference Fourier maps. Finally, they were placed at calculated positions and treated as riding model. SHELXL-97 software [23] was used for structure refinement and interpretation. Drawings of the structures were produced using ORTEP-III [24] and Mercury [25]. Structural (bond lengths and angles) and other crystallographic details on data collection and refinement have been deposited with the Cambridge Crystallographic Data Centre as supplementary publication numbers CCDC Deposition Number 2086014 and 2086013 for low (APO-Tric-LT) and room temperature (APO-Tric-RT) data, respectively. These data can be obtained free of charge via www.ccdc.cam.ac.uk/conts/retrieving.html (accessed on 26 May 2021) (or from the CCDC, 12 Union Road, Cambridge CB2 1EZ, UK; 
fax: +44 1223 336033; e-mail: deposit@ccdc.cam.ac.uk. Nitrogen physisorption measurements were obtained at $-196{ }^{\circ} \mathrm{C}$ on a Quantachrom autosorb iQ3 instrument. Before the meauserment, samples were outgassed under vacuum for $16 \mathrm{~h}$ at $150{ }^{\circ} \mathrm{C}$. The BET specific surface area, $\mathrm{S}_{\mathrm{BET}}$ was calculated using the adsorption branch. The total pore volume, $\mathrm{Vt}$, was estimated from the amount adsorbed at a relative pressure of 0.95 . Water sorption characteristic of the sample was determined by an IGA-100 gravimetric analyzer (Hiden Isochema Ltd., Warrington, UK) at $25^{\circ} \mathrm{C}$. Before adsorption measurements, the samples were outgassed to a constant weight under ultrahigh vacuum $\left(<10^{-5} \mathrm{mbar}\right)$ at $150{ }^{\circ} \mathrm{C}$ for $5 \mathrm{~h}$.

\section{Results and Discussion}

Crystalline APO-Tric powder was first obtained from the ionogel containing 1-ethyl-3methylimidazolium bromide at ambient pressure at $200^{\circ} \mathrm{C}$ after 3 days. Longer crystallization time led to the formation of $\mathrm{AlPO}_{4}-11$, product with a different crystal structure and AEL topology. Contrary, pure APO-Tric crystals were crystallized at an elevated pressure ionothermal synthesis only after longer crystallization time (6 days). Pure APO-Tric powder was obtained via ionothermal route at shorter crystallization time (5 days), only when lower (half) amount of the ionic liquid was used for the ionogel preparation. When crystallization was extended, non-porous phase (i.e., crystobalite) was obtained.

Figure 1 shows powder XRD patterns of the as-synthesised sample obtained at $200{ }^{\circ} \mathrm{C}$ after 3 days at ambient pressure (APO-Tric-AP) and 5 days at elevated pressure (APO-Tric$\mathrm{EP})$, which reveal the chabazite framework with triclinic symmetry [26] of the samples. The calculated XRD pattern was determined on the basis of the single-crystal XRD data of APO-Tric obtained at elevated pressure at $200{ }^{\circ} \mathrm{C}$ after 6 days. The sample prepared at ambient pressure shows wider diffraction maxima than the sample prepared at elevated pressure (Figure 1a). Figure 1b shows XRD patterns of as-synthesised APO-Tric samples prepared form fresh and reused ionic liquid, showing highly crystalline products.
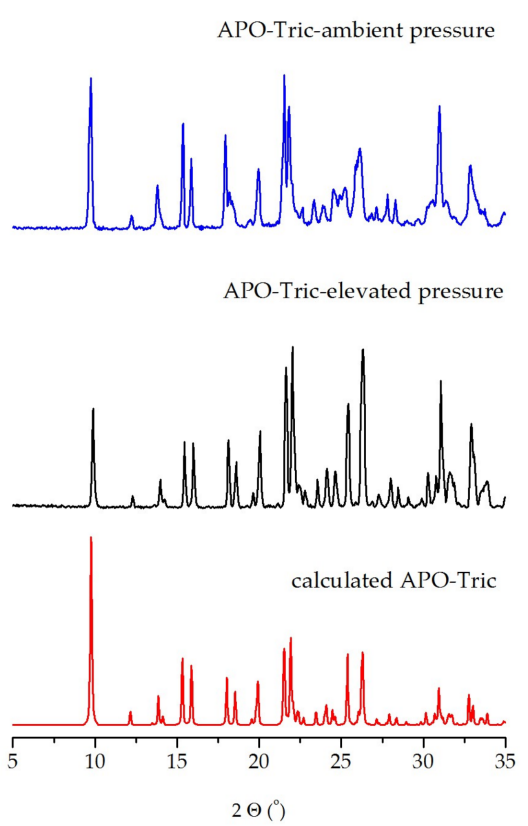

(a)

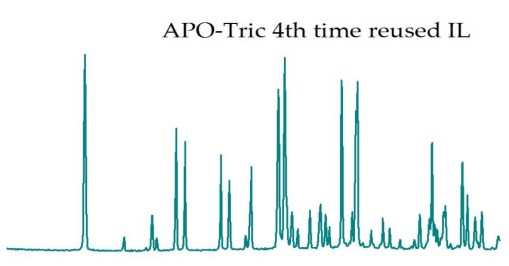

APO-Tric 1st time reused IL

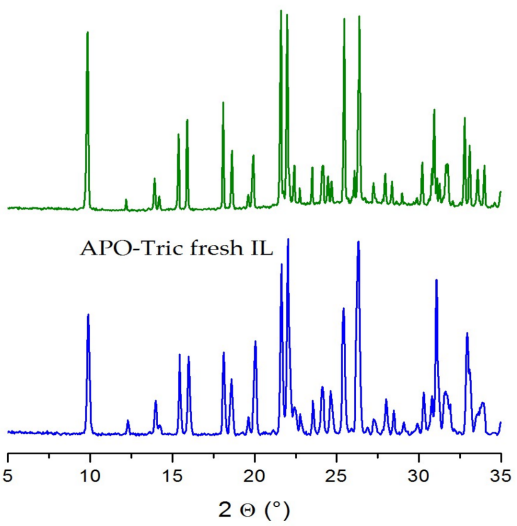

(b)

Figure 1. (a) XRD patterns of the as-synthesised APO-Tric obtained at $200{ }^{\circ} \mathrm{C}$ after 3 days at ambient pressure (top), 5 days at elevated pressure (middle), and the calculated APO-Tric (bottom); (b) XRD patterns of the as-synthesised APO-Tric from fresh IL (bottom), 1st time reused IL (middle) and 4th time reused IL (top). 
Large crystals of $200 \mu \mathrm{m}$ with romboid shape (prism) were prepared after 6 days at elevated pressure (Figure 2a). 10-20 $\mu \mathrm{m}$ hexagonal prisms composed of nanosized particles were obtained at ambient pressure as it can be seen in Figure 2b, while agglomerated rectangular prisms of $20 \mu \mathrm{m}$ were obtained after 5 days (Figure 2c). Ionothermal synthesis at elevated pressure thus favors formation of rectangular shape of crystallites.

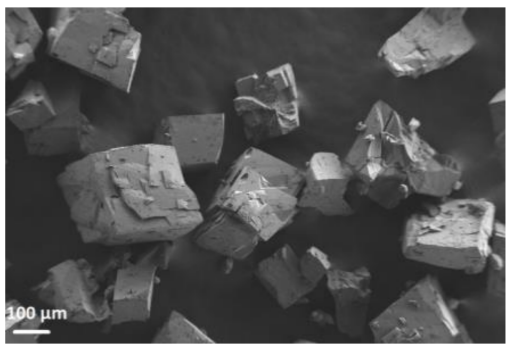

(a)

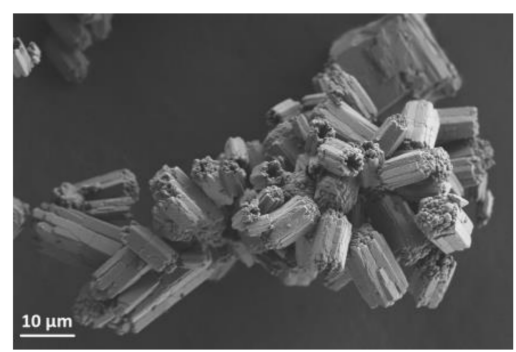

(b)

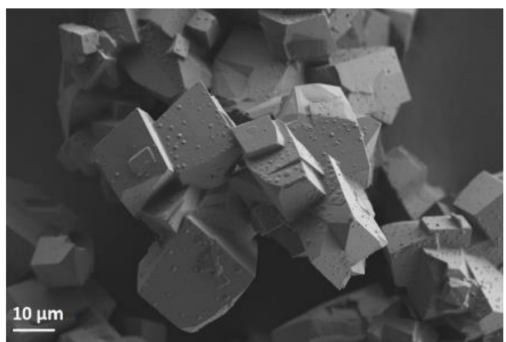

(c)

Figure 2. SEM micrograph of the as-synthesised APO-Tric samples prepared at $200{ }^{\circ} \mathrm{C}$ : (a) 6 days at elevated pressure, (b) 3 days at ambient pressure and (c) 5 days at elevated pressure.

Large $200 \mu \mathrm{m}$ crystals of the as-synthesised APO-Tric (elevated pressure) were used for a single-crystal X-ray diffraction determination. The structure was determined at room temperature (RT) and at $150 \mathrm{~K}(\mathrm{LT})$, showing the triclinic deformation of chabazite framework [26] at both temperatures with 1,3-dimethylimidazolinium cation placed in the pores. The crystal data for the structure determined at room temperature (APO-Tric -RT) and at 150 K (APO-Tric -LT) are shown in Table S1 (see in Supplementary Materials). Here we show the crystal data determined at room temperature (APO-Tric -RT): $\mathrm{C}_{5} \mathrm{H}_{9} \mathrm{Al}_{3} \mathrm{FN}_{2} \mathrm{O}_{12} \mathrm{P}_{3}$ $(\mathrm{M}=481.99 \mathrm{~g} / \mathrm{mol})$ : triclinic, space group $\mathrm{P}-1$ (no. 2), $\mathrm{a}=9.0875(5) \AA, \mathrm{b}=9.2281(5) \AA$, $c=9.3073(5) \AA, \alpha=76.515(5)^{\circ}, \beta=87.258(4)^{\circ}, \gamma=89.442(4)^{\circ}, V=758.13(7) \AA^{3}, Z=2$, $\mathrm{T}=293(2) \mathrm{K}, \mu(\mathrm{MoK} \alpha)=0.653 \mathrm{~mm}^{-1}$, Dcalc $=2.111 \mathrm{~g} / \mathrm{cm}^{3}, 6652$ reflections measured $\left(2.8^{\circ} \leq 2 \theta \leq 30.5^{\circ}\right), 3925$ unique (Rint $=0.035$, Rsigma $\left.=0.101\right)$ which were used in all

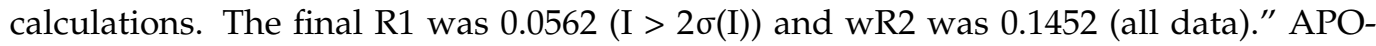
Tric -LT (Figure 3) and APO-Tric-RT (Figure 4) structures are practically the same. With lowering of temperature from 293 to $150 \mathrm{~K}$ the structure only slightly contracts along all three unit cell axis, resulting in slightly smaller unit cell. As expected displacement parameters of atoms in APO-Tric-LT are smaller due to less thermal motion of atoms, which can be seen by the comparison of ORTEP figures of asymmetric units of both structures (Figure 4). The asymmetric unit consists in both cases of three Al, three $\mathrm{P}, 12 \mathrm{O}$, one $\mathrm{F}$ atom and one 1,3-dimethylimidazolium cation. The structure at $150 \mathrm{~K}$ had been already determined using synchrotron $\mathrm{X}$-ray diffraction data using a single crystal obtained from the ionogel containing 1-buthyl-3-methylimidazolium chloride ionic liquid [27]. We performed laboratory-based structure analysis using single crystal and obtained positions of framework and template atoms including $\mathrm{H}$ atoms. In the asymmetric unit $\mathrm{Al}$ and $\mathrm{P}$ atoms occupy three different crystallographic sites on general positions. All three P atoms and two Al atoms are tetrahedrally coordinated by four $\mathrm{O}$ atoms. Al1 is octahedrally coordinated by four $\mathrm{O}$ atoms and two apical $\mathrm{F}$ atoms. Tetrahedrons and octahedrons with alternating $\mathrm{P}$ and $\mathrm{Al}$ central atoms are connected via corners into negatively charged three-dimensional framework with the largest channels running parallel all three unit cell axes. These channels are confined by eight-membered rings. At the intersections of channels there are small cages, where 1,3-dimethylimidazolium cations are placed, which balance the negative charge of the framework. 


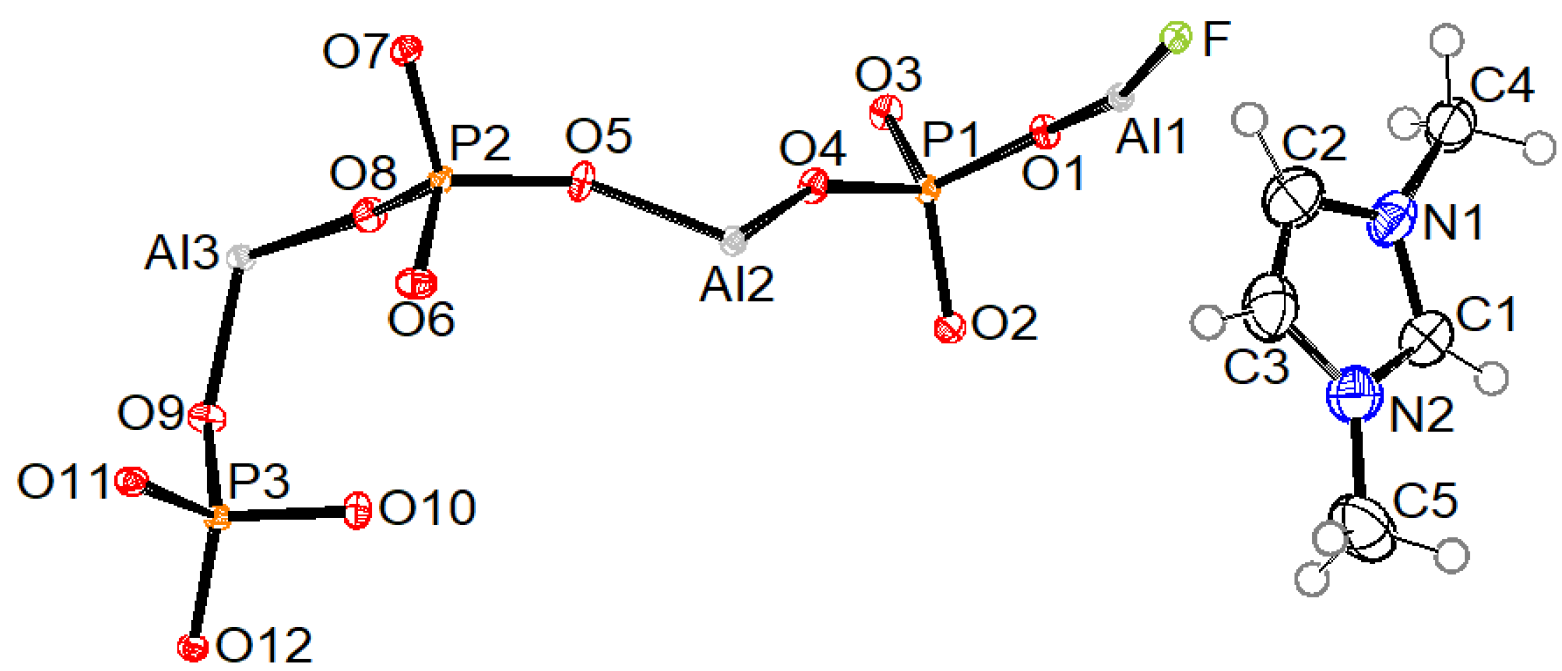

Figure 3. ORTEP drawing of asymmetric unit of the as-synthesised APO-Tric -LT. Ellipsoids are represented at the $50 \%$ probability level.

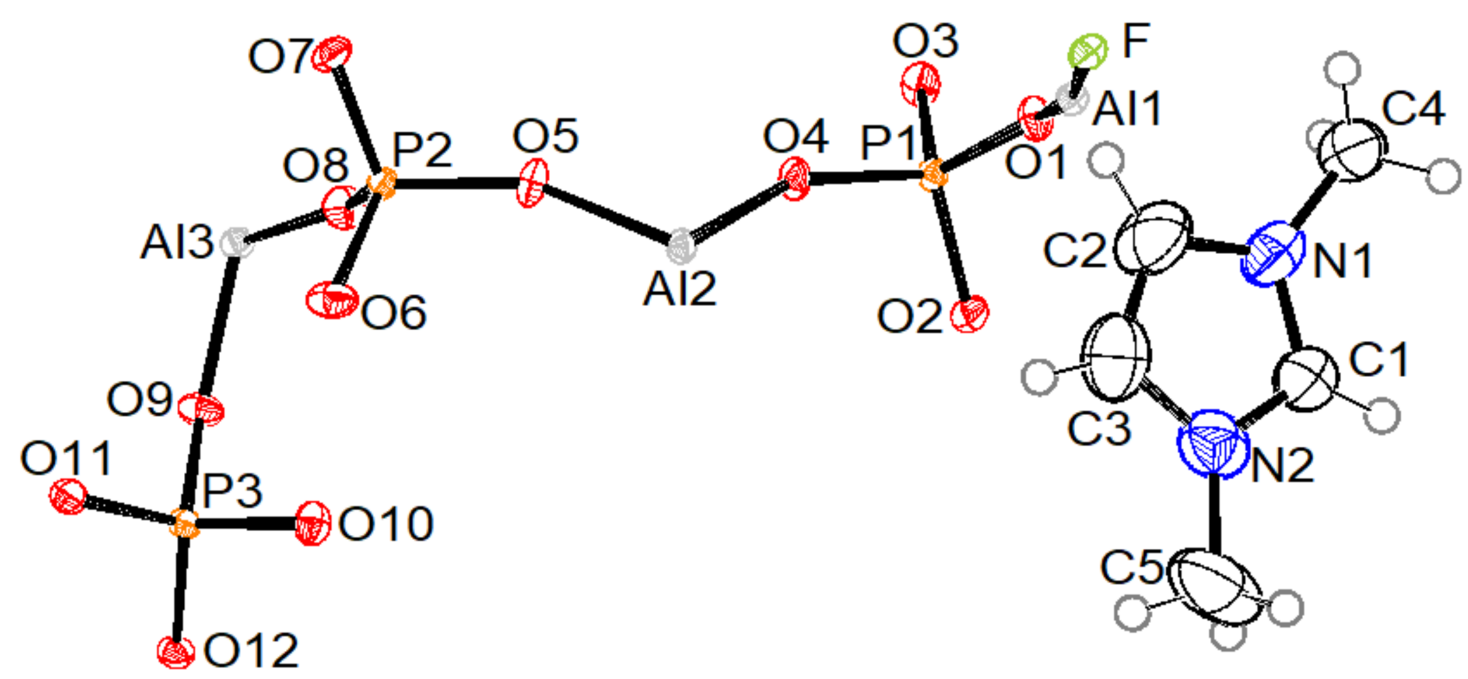

Figure 4. ORTEP drawing of asymmetric unit of the as-synthesised APO-Tric -RT. Ellipsoids are represented at the $50 \%$ probability level.

In each pore there are two parallel cations which are symmetry related by a centre of symmetry in the centre of pore (Figure 5). The distance between the ring centroids is 3.728(2) $\AA$ in APO-Tric-LT and 3.766(2) $\AA$ in APO-Tric-RT which means that both structures are additionally stabilised via $\pi-\pi$ interactions of aromatic rings.

Beside the stabilising contacts between parallel cations within the cage, there are also van der Waals interactions among cations from the neighbouring cages, shown in Figure 6. This figure shows also intermolecular interactions with corresponding contact distances (A) between cation and framework.

The interesting observation is, that during crystallization trans-alkylation of 1-ethyl3-methylimidazolium bromide occurred in the presence of HF, leading to the formation of 1,3-dimethylimidazolinium cation, which was encapsulated in the pores. This phenomenon was, for example, observed for 1-propyl-3-methylimidazolium, 1-butyl-3methylimidazolium and 1-pentil-3-methylimidazolium chlorides [27,28], but up till now not for 1-ethyl-3-methylimidazolium bromide. Namely, when 1-ethyl-3-methylimidazolium bromide was used by Morris, 1-ethyl-3-methylimidazolium cations were detected also in the crystals. Griffin [29] explained that the reason could be the presence of a more nucleophilic anion $\left(\mathrm{Cl}^{-}\right)$in the ionogel. 


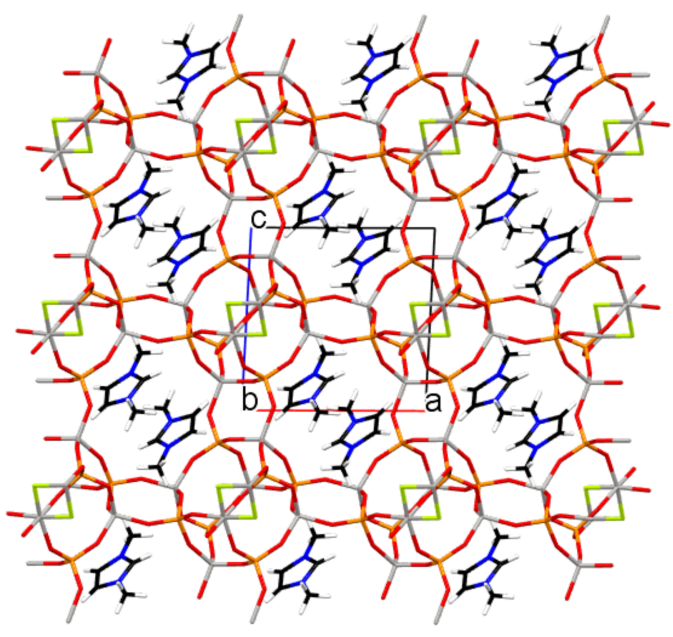

(a)

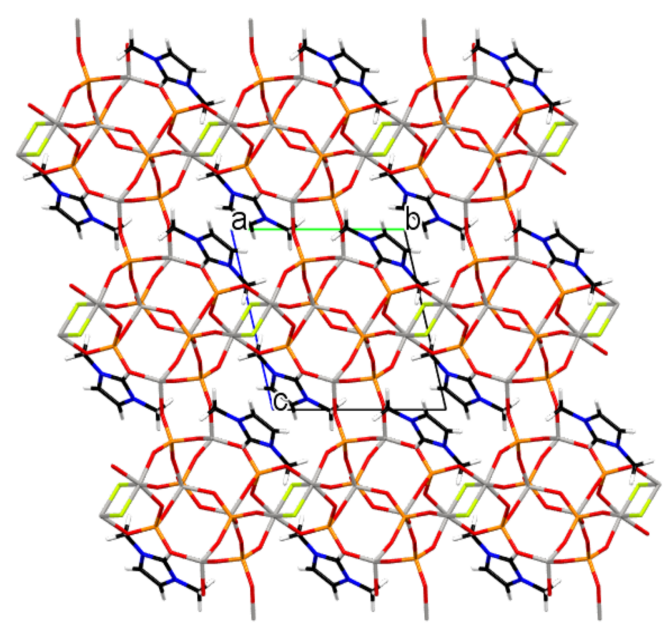

(b)

Figure 5. Mercury drawing showing a crystal packing in the as-synthesised APO-Tric-LT. The orange, gray, red, yellowgreen, black, blue and white sticks represent $\mathrm{P}, \mathrm{Al}, \mathrm{O}, \mathrm{F}, \mathrm{C}, \mathrm{N}$ and $\mathrm{H}$ atoms, respectively. (a): view on the structure along $b$ axis and (b): along $a$ axis.

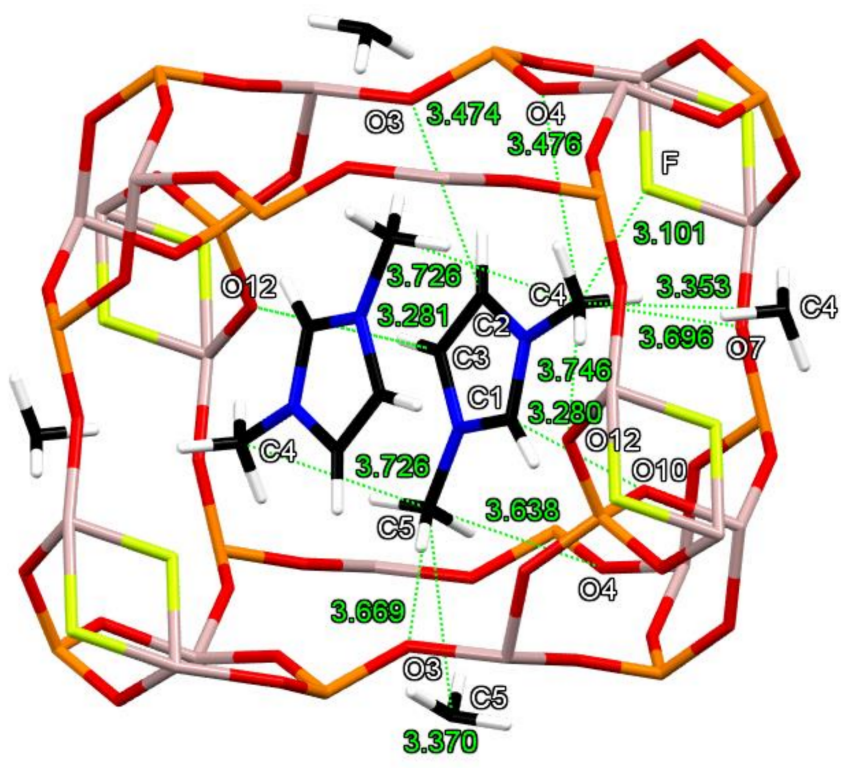

Figure 6. Mercury drawing of the content of one cage showing contact distances $(\AA)$ of stabilising interactions among cations and those between cations and framework in APO-Tric-LT. Due to clarity only contact distances of one cation from the cage are shown. Contact distances of the other are the same due to the symmetry. The orange, gray, red, yellow-green, black, blue and white sticks represent $\mathrm{P}, \mathrm{Al}, \mathrm{O}, \mathrm{F}, \mathrm{C}, \mathrm{N}$ and $\mathrm{H}$ atoms, respectively.

The amount of 1,3-dimetylimidazolium cation in the samples was further determined with thermogravimetry. Figure 7 shows TG/DTG curves of the as-synthesised sample prepared at the elevated pressure (top) from the ionogel containing half amount of the ionic liquid. Total weight loss was determined to be $25.4 \%$. TG/DTG curves of this sample show water loss of $1.2 \%$ up to $250{ }^{\circ} \mathrm{C}$ and mass loss of $24.2 \%$ between 250 and $600{ }^{\circ} \mathrm{C}$ due to decomposition and release of 1,3-dimethylimidazolinium cation and fluoride per $\left[\mathrm{AlPO}_{4}\right]_{3}$ formula unit (calculated $24.1 \%$ ). The sample prepared at ambient pressure shows different TG/DTG curves. Total weight loss is lower (19.9\%) with larger water loss (2.6\%) up to $250^{\circ} \mathrm{C}$. 


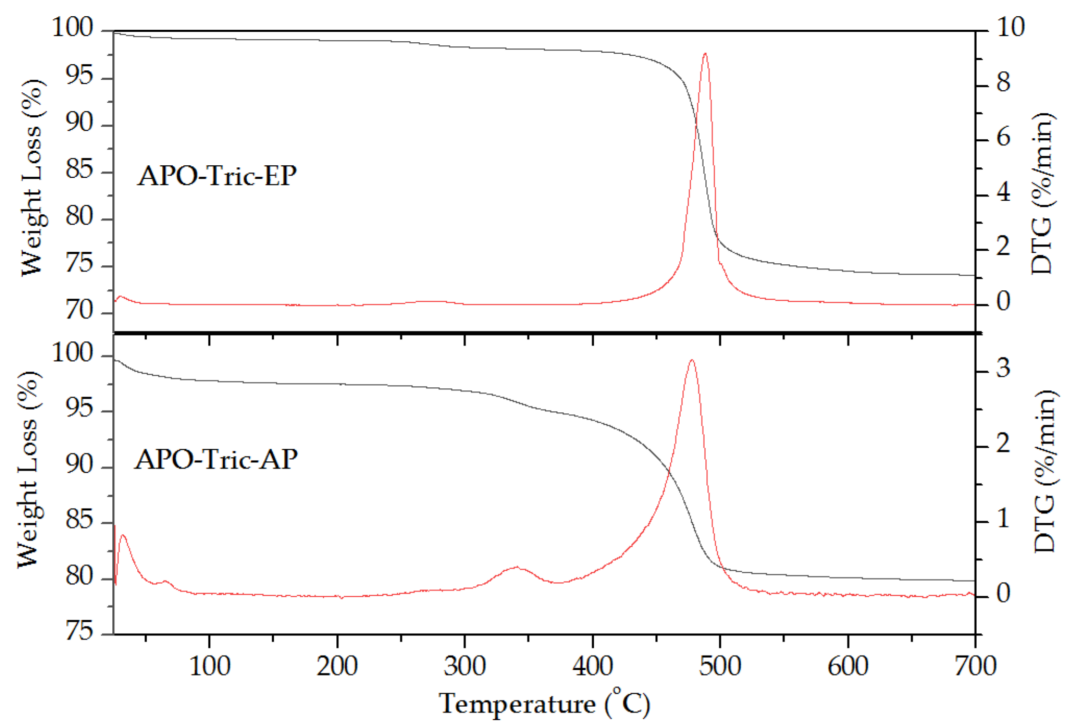

Figure 7. TG/DTG curves of the as-synthesised APO-Tric -EP (top) and APO-Tric -AP powders (bottom).

Desorption temperature of both hydrated calcined samples was determined from DTG curves [30] in Figure 8. Two different desorption sites for water molecules can be observed in the APO-Tric-EP sample, i.e., at $30^{\circ} \mathrm{C}$ and at $68^{\circ} \mathrm{C}$. Desorption temperature is lower for $30{ }^{\circ} \mathrm{C}$ comparing to the hydrothermally prepared sample [31]. The water loss of the sample prepared at elevated pressure is higher to the water loss of the sample obtained from the ionogel at ambient pressure, which can be due to lower crystallinity of this sample clearly seen in Figure 1a. Desorption temperatures of APO-Tric-AP is $47^{\circ} \mathrm{C}$. Hydrothermally prepared sample APO-Tric showed 23\% water loss (Figure S1 see in Supplementary Material).

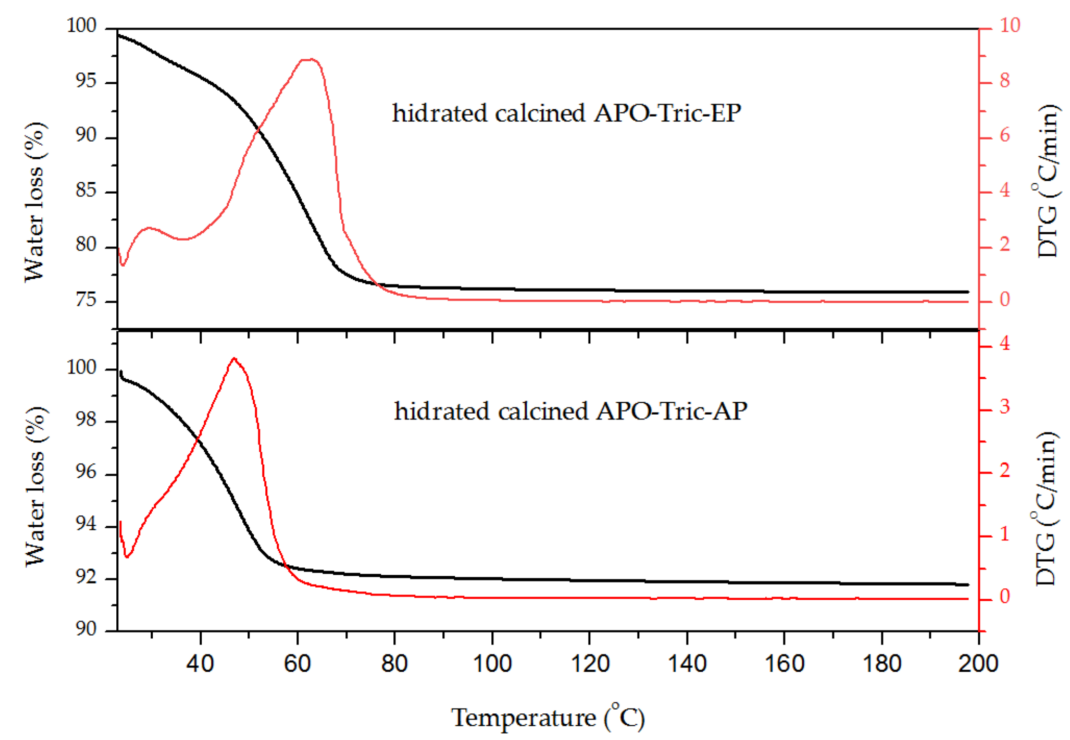

Figure 8. TG/DTG curves of hydrated calcined APO-Tric-EP (top) and APO-Tric-AP powders (bottom).

Thermal stability of the sample's structure prepared by ionothermal elevated synthesis was checked by high temperature X-Ray diffraction (Figure 9) and compared to the hydrothermally prepared sample [31]. The analysis revealed comparable stability of both samples, through symmetry changes from triclinic (room temperature to $400{ }^{\circ} \mathrm{C}$ ) to rhombohedral $\left(\mathrm{AlPO}_{4}-34\right)\left(500-600^{\circ} \mathrm{C}\right)$ and after cooling to room temperature $\left(25^{\circ} \mathrm{C}\right)$ to 
new triclinic symmetry due to the air humidity [32]. These symmetry changes of the assynthesised triclinic $\mathrm{AlPO}_{4}-34$ to dehydrated calcined rhombohedral $\mathrm{AlPO}_{4}-34$ to hydrated calcined new triclinic $\mathrm{AlPO}_{4}-34$ are well known [33]. Material retained rhombohedral symmetry after dehydration. This deformation due to hydration and dehydration is completely reversible.

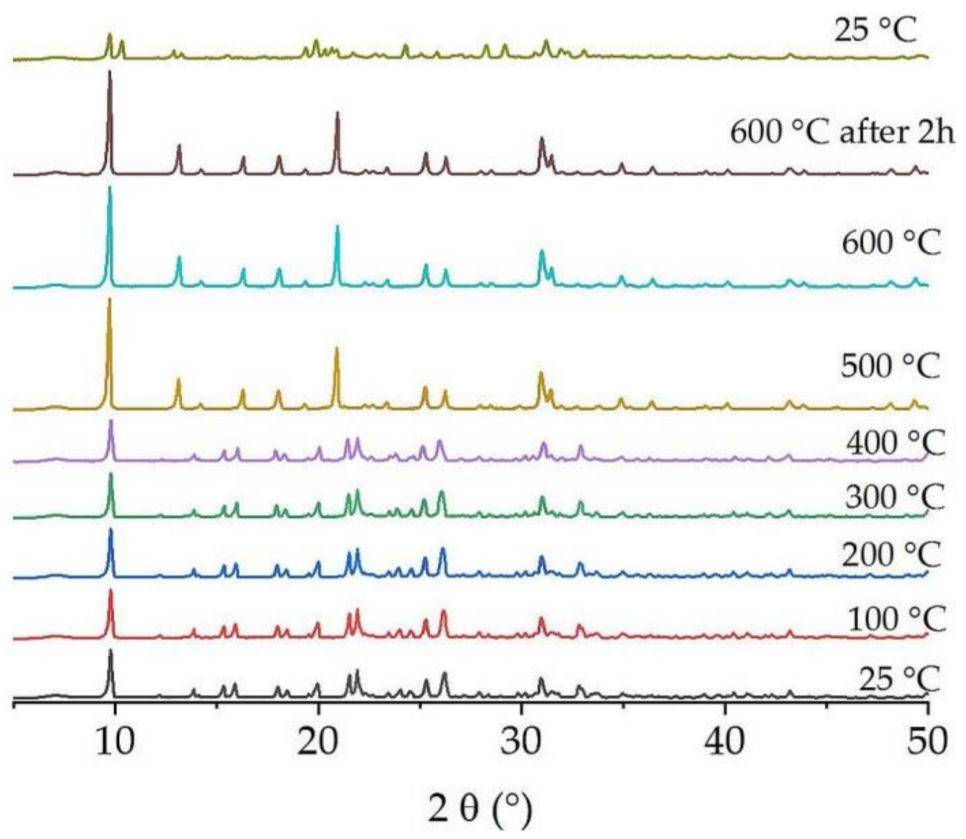

Figure 9. High Temperature XRD of the as-synthesised APO-Tric-EP.

Textural properties of the sample prepared from the ionogel with fresh IL at elevated pressure revealed specific surface area of $778 \mathrm{~m}^{2} / \mathrm{g}$ and total pore volume of $0.281 \mathrm{~cm}^{3} / \mathrm{g}$, while the sample prepared from the hydrogel showed lower specific surface area $\left(422 \mathrm{~m}^{2} / \mathrm{g}\right)$ and total pore volume $\left(0.221 \mathrm{~cm}^{3} / \mathrm{g}\right)$. Textural properties of the sample prepared from the reused IL $\left(765 \mathrm{~m}^{2} / \mathrm{g} ; 0.310 \mathrm{~cm}^{3} / \mathrm{g}\right)$ were similar to the sample prepared from the ionogel with fresh IL.

Hydrophilic properties were determined for the calcined samples prepared from ionogel at elevated (IL) and of the sample prepared from hydrogel (HT) at elevated pressure by gravimetric water sorption analysis. Maximal water adsorption capacity of APO-Tric-IL (elevated) ionothermally synthesised was determined at relative pressure of 0.8 , which is similar (32.8\%) to the material prepared from the hydrogel (APO-Tric-HT). Furthermore, different types of water isotherms can be observed, as shown in Figure 10. The APO-Tric-IL exhibit type I isotherm with less steep uptake, indicating on more hydrophilic character than APO-Tric-HT, while hydrothermally prepared sample APO-Tric-HT shows typical V type isotherm of hydrophobic-hydrophilic character. It can be concluded that the synthesis path influences the hydrophilic character of the product. The water uptake of APO-Tric -IL prepared from the ionogel determined at the relative pressure 0.3 is higher for $10 \%$ than the water uptake of the APO-Tric -HT sample obtained from the hydrogel, which can be explained by the formation of the sample with higher specific surface area and larger pore volume [30] after removal of the template. It is known that during synthesis different templates lead to formation of chabazite structures with various crystal unit cells [34] or local disorder in crystals [35], which can influence the creation of different structural defects as possible adsorption sites and is in accordance with determined large specific surface area and pore volume [30]. 


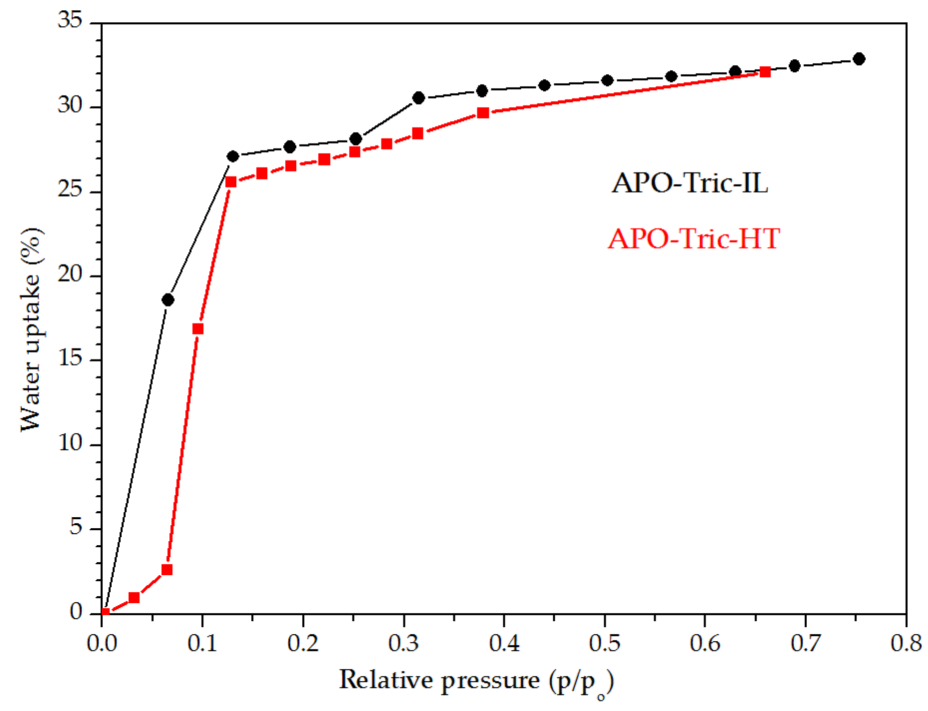

Figure 10. Water adsorption isotherms of calcined APO-Tric prepared from ionogel (APO-Tric -IL) at elevated pressure and from hydrogel (APO-Tric -HT) at elevated pressure.

\section{Conclusions}

The crystalline microporous APO-Tric was synthesised at ambient and elevated pressure using 1-ethyl-3-methylimidazolium bromide ionic liquid as solvent and structure directing agent, which led to the formation of the adsorbent with high thermal stability up to $600{ }^{\circ} \mathrm{C}$ and enhanced hydrophilic character. Duration of crystallization at elevated pressure increased product particle size from 20 to $200 \mu \mathrm{m}$. Single crystal XRD determination revealed the presence of 1,3-dimethylimidazolium cations in the pores, which were fully ordered. Hydrophilic properties were tailored by the ionothermal synthesis parameters and calcination. Although the product with stronger hydrophilic character was obtained at ionothermal synthesis at elevated pressure, the desorption temperature decreased for $30^{\circ} \mathrm{C}$.

After the crystallization the used ionic liquid was recycled and reused, showing highly crystalline products. Therefore ionothermal synthesis of aluminophosphates can reduce toxicity and cost production. In the future this approach will enable the access to topperforming aqueous adsorbents for heat storage or heat pump applications and could be a breakthrough in the low-cost industrial production of aluminophosphate adsorbents.

Supplementary Materials: The following are available online at https:/ /www.mdpi.com/article/ 10.3390/cryst11070773/s1, Table S1: Summary of crystallographic data and structure analyses of APO-Tric prepared at elevated pressure. Figure S1: TG/DTG curves of hydrated APO-Tric-HT.

Author Contributions: The following statements should be used "Conceptualization, A.R.; formal analysis, S.M., A.G.; investigation, S.M.; writing—original draft preparation, A.R., A.G..; writingreview and editing, A.R., N.Z.L.; visualization, S.M., A.R. and A.G.; supervision A.R., funding acquisition, N.Z.L. All authors have read and agreed to the published version of the manuscript.

Funding: Financial support from the Slovenian Research Agency through research program P1-0021 (Nanoporous materials) is acknowledged.

Institutional Review Board Statement: Not applicable.

Informed Consent Statement: Not applicable.

Data Availability Statement: In accordance with MDPI Research Data Policies.

Acknowledgments: We thank Edi Kranjc for XRD measurements and Mojca Opresnik for SEM pictures. 
Conflicts of Interest: The authors declare no conflict of interest. The funders had no role in: the design of the study; in the collection, analyses, or interpretation of data; in the writing of the manuscript, and in the decision to publish the results.

\section{References}

1. Henninger, S.K.; Schmidt, F.P.; Henning, H.M. Water adsorption characteristics of novel materials for heat transformation applications. Appl. Therm. Eng. 2010, 30, 1692-1702. [CrossRef]

2. Vasta, S.; Brancato, V.; La Rosa, D.; Palomba, V.; Restuccia, G.; Sapienza, A.; Frazzica, A. Adsorption Heat Storage: State-of-the-Art and Future Perspectives. Nanomaterials 2018, 8, 522. [CrossRef]

3. Ng, E.P.; Mintova, S. Nanoporous materials with enhanced hydrophilicity and high water sorption capacity. Microporous Mesoporous Mater. 2008, 114, 1-26. [CrossRef]

4. Wu, H.; Salles, F.; Zajac, J. A Critical Review of Solid Materials for Low-Temperature Thermochemical Storage of Solar Energy Based on Solid-Vapour Adsorption in View of Space Heating Uses. Molecules 2019, 24, 945. [CrossRef]

5. Liang, J.; Li, H.; Zhao, S.; Guo, W.; Wang, R.; Ying, M. Characteristics and performance of SAPO-34 catalyst for methanol-to-olefin conversion. Appl. Catal. 1990, 64, 31-40. [CrossRef]

6. Wilson, S.T.; Lok, B.M.; Messina, C.A.; Cannan, T.R.; Flanigen, E.M. Aluminophosphate Molecular Sieves: A New Class of Microporous Crystalline Inorganic Solids. J. Am. Chem. Soc. 1982, 104, 1146-1147. [CrossRef]

7. Stach, H.; Mugele, J.; Jänchen, J.; Weiler, E. Influence of cycle temperatures on the thermochemical heat storage densities in the systems water/microporous and water/mesoporous adsorbents. Adsorption 2005, 11, 393-404. [CrossRef]

8. Bonaccorsi, L.; Calabrese, L.; Freni, A.; Proverbio, E.; Restuccia, G. Zeolites direct synthesis on heat exchangers for adsorption heat pumps. In Proceedings of the Applied Thermal Engineering; Elsevier Ltd.: Amsterdam, The Netherlands, 2013; Volume 50, pp. 1590-1595.

9. Ristić, A.; Logar, N.Z.; Henninger, S.K.; Kaučič, V. The performance of small-pore microporous aluminophosphates in lowtemperature solar energy storage: The structure-property relationship. Adv. Funct. Mater. 2012, 22, 1952-1957. [CrossRef]

10. Brancato, V.; Frazzica, A. Characterisation and comparative analysis of zeotype water adsorbents for heat transformation applications. Sol. Energy Mater. Sol. Cells 2018, 180, 91-102. [CrossRef]

11. Calabrese, L.; De Antonellis, S.; Vasta, S.; Brancato, V.; Freni, A. Modified silicone-SAPO34 composite materials for adsorption thermal energy storage systems. Appl. Sci. 2020, 10, 8715. [CrossRef]

12. Krajnc, A.; Varlec, J.; Mazaj, M.; Ristić, A.; Logar, N.Z.; Mali, G. Superior Performance of Microporous Aluminophosphate with LTA Topology in Solar-Energy Storage and Heat Reallocation. Adv. Energy Mater. 2017, 7, 1601815. [CrossRef]

13. Henninger, S.K.; Munz, G.; Ratzsch, K.F.; Schossig, P. Cycle stability of sorption materials and composites for the use in heat pumps and cooling machines. Renew. Energy 2011, 36, 3043-3049. [CrossRef]

14. Drylie, E.A.; Wragg, D.S.; Parnham, E.R.; Wheatley, P.S.; Slawin, A.M.Z.; Warren, J.E.; Morris, R.E. Ionothermal synthesis of unusual choline-templated cobalt aluminophosphates. Angew. Chemie Int. Ed. 2007, 46, 7839-7843. [CrossRef] [PubMed]

15. Rogers, R.D.; Seddon, K.R. Ionic Liquids-Solvents of the Future? Science (80-.) 2003, 302, 792-793. [CrossRef] [PubMed]

16. Meng, X.; Xiao, F.S. Green routes for synthesis of zeolites. Chem. Rev. 2014, 114, 1521-1543. [CrossRef] [PubMed]

17. Hayes, R.; Warr, G.G.; Atkin, R. Structure and Nanostructure in Ionic Liquids. Chem. Rev. 2015, 115, 6357-6426. [CrossRef]

18. Cooper, E.R.; Andrews, C.D.; Wheatley, P.S.; Webb, P.B.; Wormald, P.; Morris, R.E. Ionic liquids and eutectic mixtures as solvent and template in synthesis of zeolite analogues. Nature 2004, 430, 1012-1016. [CrossRef] [PubMed]

19. Baerlocher, C.; Meier, W.M.; Olson, D.H. Atlas of Zeolite Framework Types; Elsevier: Amsterdam, The Netherlands, 2007.

20. Musa, M.; Dawson, D.M.; Ashbrook, S.E.; Morris, R.E. Ionothermal synthesis and characterization of CoAPO-34 molecular sieve. Microporous Mesoporous Mater. 2017, 239, 336-341. [CrossRef]

21. Rigaku Oxford Diffraction. CrysAlis Pro. Version 1.171.38.46; Rigaku Corporation: Oxford, UK, 2015.

22. Altomare, A.; Burla, M.C.; Camalli, M.; Cascarano, G.L.; Giacovazzo, C.; Guagliardi, A.; Moliterni, A.G.G.; Polidori, G.; Spagna, R. SIR97: A new tool for crystal structure determination and refinement. J. Appl. Crystallogr. 1999, 32, 115-119. [CrossRef]

23. Sheldrick, G.M. A short history of SHELX. Acta Crystallogr. Sect. A Found. Crystallogr. 2008, 64, 112-122. [CrossRef]

24. Farrugia, L.J. ORTEP-3 for windows-A version of ORTEP-III with a graphical user interface (GUI). J. Appl. Crystallogr. 1997, 30, 565. [CrossRef]

25. Macrae, C.F.; Edgington, P.R.; McCabe, P.; Pidcock, E.; Shields, G.P.; Taylor, R.; Towler, M.; Van De Streek, J. Mercury: Visualization and analysis of crystal structures. J. Appl. Crystallogr. 2006, 39, 453-457. [CrossRef]

26. Harding, M.M.; Kariuki, B.M. Microcrystal structure determination of AlPO4-CHA using synchrotron radiation. Acta Crystallogr. Sect. C Cryst. Struct. Commun. 1994, 50, 852-854. [CrossRef]

27. Parnham, E.R.; Morris, R.E. 1-Alkyl-3-methyl imidazolium bromide ionic liquids in the ionothermal synthesis of aluminium phosphate molecular sieves. Chem. Mater. 2006, 18, 4882-4887. [CrossRef]

28. Parnham, E.R.; Morris, R.E. Ionothermal synthesis of zeolites, metal-organic frameworks, and inorganic-organic hybrids. Acc. Chem. Res. 2007, 40, 1005-1013. [CrossRef] [PubMed]

29. Griffin, J.M.; Clark, L.; Seymour, V.R.; Aldous, D.W.; Dawson, D.M.; Iuga, D.; Morris, R.E.; Ashbrook, S.E. Ionothermal 17O enrichment of oxides using microlitre quantities of labelled water. Chem. Sci. 2012, 3, 2293-2300. [CrossRef] 
30. Ristić, A.; Fischer, F.; Hauer, A.; Zabukovec Logar, N. Improved performance of binder-free zeolite y for low-temperature sorption heat storage. J. Mater. Chem. A 2018, 6, 11521-11530. [CrossRef]

31. Varlec, J.; Krajnc, A.; Mazaj, M.; Ristić, A.; Vanatalu, K.; Oss, A.; Samoson, A.; Kaučič, V.; Mali, G. Dehydration of AlPO 4 -34 studied by variable-temperature NMR, XRD and first-principles calculations. New J. Chem. 2016, 40, 4178-4186. [CrossRef]

32. Ristić, A.; Tušar, N.N.; Arčon, I.; Thibault-Starzyk, F.; Hanžel, D.; Czyzniewska, J.; Kaučič, V. Synthesis and characterization of triclinic MeAPO-34 (Me = Zn, Fe) molecular sieves. Microporous Mesoporous Mater. 2002, 56, 303-315. [CrossRef]

33. Tuel, A.; Caldarelli, S.; Meden, A.; McCusker, L.B.; Baerlocher, C.; Ristic, A.; Rajic, N.; Mali, G.; Kaucic, V. NMR characterization and rietveld refinement of the structure of rehydrated AlPQ4-34. J. Phys. Chem. B 2000, 104, 5697-5705. [CrossRef]

34. Fischer, M. Template effects on the pressure-dependent behavior of chabazite-type fluoroaluminophosphates: A computational approach. Phys. Chem. Miner. 2019, 46, 385-401. [CrossRef]

35. Dawson, D.M.; Griffin, J.M.; Seymour, V.R.; Wheatley, P.S.; Amri, M.; Kurkiewicz, T.; Guillou, N.; Wimperis, S.; Walton, R.I.; Ashbrook, S.E. A multinuclear NMR study of six forms of AlPO-34: Structure and motional broadening. J. Phys. Chem. C 2017, 121, 1781-1793. [CrossRef] 